\title{
Vailati, Papini, and the Synthetic Drive of Italian Pragmatism
}

\section{Giovanni Maddalena}

\section{(2) OpenEdition}

1 Journals

Electronic version

URL: http://journals.openedition.org/ejpap/1533

DOI: 10.4000/ejpap.1533

ISSN: 2036-4091

\section{Publisher}

Associazione Pragma

\section{Electronic reference}

Giovanni Maddalena, « Vailati, Papini, and the Synthetic Drive of Italian Pragmatism », European Journal of Pragmatism and American Philosophy [Online], XI-1 | 2019, Online since 19 July 2019, connection on 21 July 2019. URL : http://journals.openedition.org/ejpap/1533 ; DOI : 10.4000/ejpap.1533

This text was automatically generated on 21 July 2019

\section{(c) $($ ) $(9)$}

Author retains copyright and grants the European Journal of Pragmatism and American Philosophy right of first publication with the work simultaneously licensed under a Creative Commons AttributionNonCommercial-NoDerivatives 4.0 International License. 


\title{
Vailati, Papini, and the Synthetic Drive of Italian Pragmatism
}

\author{
Giovanni Maddalena
}

\section{Introduction}

1 According to the standard interpretation, Italian pragmatism is split into two groups. On the one hand is the mathematician Giovanni Vailati, Peano's former collaborator, and his disciple, the economist Mario Calderoni. On the other hand, there are the two "brats," Giovanni Papini and Giuseppe Prezzolini, naïve philosophers with eccentric ideas. While Vailati and Calderoni followed Peirce's mathematical and logical pragmatism, the other two articulated a "magical" pragmatism, a kind of relativist, post-modern version of the original American movement. This latter view can be found in Papini's description of it, ${ }^{1}$ and the twofold description of the Italian pragmatism has become a common place of the scholarship. However, our knowledge of the development of pragmatism and of contemporary mathematics allow us to suggest a more precise definition of the Italian movement.

\section{A Three Stripes Story}

2 Let us start by examining the standard interpretation. The source of this twofold narrative can be found in the dialectical exchange between Calderoni and Prezzolini in November 1904 and February 1905 numbers of Leonardo, the journal that Papini founded in 1903. ${ }^{2}$ This narrative is at the heart of De Waal's reconstruction of the period (DeWaal 2004), and may also be found in Colapietro (2007) and in other Italian scholars, such as Garin (1963), Santucci (1963), and Dal Pra (1984). The narrative is, however, not completely accurate. The April 1905 number of Leonardo contained the article "Il pragmatismo messo in ordine" authored by the Florentine Pragmatist Club, which listed and described three kinds of pragmatism in Italy (L III/2, aprile 1905: 45-7). The first was "loyal" to Peirce's maxim, and apparently took Calderoni as the Italian representative. 
The second, denoted as "magical pragmatism," focused on the "Will to believe" as a power capable of transforming reality. Prezzolini and Papini were identified as belonging to this camp. In the middle, there was a third stripe represented by those who thought that Peirce's maxim was a logical tool for making free choices among various kinds of postulates. Vailati probably fell into this group. This article concludes with the metaphor of pragmatism as a "corridor" that James liked so much and attributed to Papini. ${ }^{3}$ The articulation of three kinds of Italian pragmatism appeared again in Papini's February 1906 article "Cronaca pragmatista," dedicated to pragmatism and politics (L IV/5, Febbraio 1906: 58-61). The article is open to the notion that there may be even more than three varieties of pragmatism, a pluralism which, for Papini, is a cause for rejoicing. Thus, even if Papini sometimes presented the "two pragmatisms" theory in subsequent writings, the two stripes theory is, even from Papini's point of view, somewhat misleading.

3 Connected to the misleading notion of "two pragmatisms," there is a notorious and mistaken legend that Papini and Prezzolini somehow influenced the rise of fascism. ${ }^{4}$ Curiously, very good scholars like Colapietro (2007) and Bordogna (2015) seem to have accepted this misconception. At the bottom of this philosophical "fake news" was a statement by Mussolini himself who, in an interview with the New York Times Magazine in 1926, cited William James as one of his philosophical models (O'Hare 1926; Livingston 2016). The post hoc ergo propter hoc fallacy runs as follows: Papini imported William James's thought into Italy, Mussolini liked James, and therefore Papini was responsible for inspiring Mussolini and fascism. The origin of the fallacious reasoning was an article by Herbert Read in the Spectator from October 23, 1936 hinting that Papini and Leonardo were responsible for Mussolini's acquaintance with James and pragmatism. According to Read, further proof was supplied by the fact that Mussolini wrote for Leonardo. The story was completed with the considerations that fascism proclaimed action and an accompanying transformation of reality as its aims and that Mussolini quoted a statement by James about "action being judged by results and not by its doctrine" (Read 1936). How could one doubt the connection?

4 I presented some counterarguments to this fable in a book I wrote some years ago with Giovanni Tuzet (Maddalena \& Tuzet 2007). Some facts may be helpful to set the argument. Papini shut down Leonardo in 1907, and at that time he considered his pragmatist phase to be at an end, so much so that James asked in a letter where that genial "dago" ended up (CWJ, 12.209). In 1907 Mussolini was 24 and a self-proclaimed socialist. His favorite readings were by Marx and Schopenhauer. Fascism was born in 1919; by that time, Papini was about to convert to Catholicism. Fascism considered Giovanni Gentile's idealism to be its official philosophy. Gentile, not Papini, was called to serve as Mussolini's Minister of Education. Also, while it is possible that Mussolini remembered something from Leonardo from 19 years before, there is no proof that he ever read the journal. Read's statement that Mussolini was a cooperator with Leonardo is simply false - he never wrote for the journal. In addition, Mussolini's quote from James does not accurately summarize any of the three forms of pragmatism as described in Leonardo. At that time almost every philosophy was talking about action, including Marxism, to which the young Mussolini was certainly close. Further, the political ideas of Leonardo reflected a profound individualism, a clear allegiance to liberalism, and sometimes, in Vailati's writing, some appreciation for Fabianism, a doctrine that mingled socialism and liberalism. ${ }^{5}$ It is hard to get politically further away from fascism than these ideas. Finally, it should be noted that 
Papini became a fascist much later, in 1935. He had dismissed pragmatism as youthful attraction and a mistake as early as 1908, and had then become a follower of theosophy, then a futurist, then a Catholic. Facing all these facts, the idea of locating the fundamental link between Papini and fascism in pragmatism seems to be at least arbitrary.

Returning to theory, there is a further question about Vailati, one of the "good guys" of the standard view. Which was his kind of pragmatism? According to the standard view he should have anticipated analytic philosophy. Is this true? Yes and no. He certainly advocated for precision of thought and language. He anticipated Wittgenstein's idea of philosophy as therapy that reduces metaphysical problems to language issues. He appreciated the contemporary development of logic, to which he had contributed by assisting Peano in the compilation of the Formulario. Finally, Vailati hated vagueness. No wonder that many years after his death he was quoted in the Vienna Circle Manifesto as a possible precursor. However, as I have noted elsewhere (Maddalena 2007), Vailati had a strong consciousness of the evolutionary historicity of truth. He even allowed for a description of science as a "lie," in accord with a sort of pre-Rortyan view of science fostered by Prezzolini among the Leonardians. ${ }^{6}$ Moreover, because of his acknowledgement of the role of historicity, Vailati was a fervent anti-Kantian and agreed with Papini's attacks on the definition of a priori necessities, whether synthetic or analytic. ${ }^{7}$ The third kind of pragmatism, the one adhered to by Vailati according to the Florentine Pragmatist Club, relied upon a very close link between ethical choices - even in an open and declared Nietzschean spirit - and logical/mathematical deductions. Vailati understood pragmatism as a way to verify consequences but had a sophisticated view of the psychology that runs beneath the surface of logic. For this kind of psychology Vailati relied on Brentano's views and his distinctions among representations, beliefs, and volitions. Of these three states of consciousness that respectively refer to sensations (which can also be images, ideas, or memories), previsions (which can be beliefs, doubts, fears, satisfactions, etc.), and value judgments, Vailati is primarily interested in the reflection or the impact they have on logic. The first category, representation, is reflected in "definitions," "propositions that have the sole purpose of clarifying and analyzing the meaning of a word or of a sentence" (S II: 88). Definitions can be analyzed as "data" but do not produce new knowledge. The expansion of knowledge, instead, is given to beliefs that are reflected in statements regarding "matters of fact," opinions that may be true or false "independently of any human convention on the way of expressing them" (S II: 88). Here ideas and facts find their unity. This level of experience is the one in which hypotheticaldeductive knowledge works. Finally, there are volitions, the "value judgments" which find their logical equivalent in the choice of postulates or of the "table of values" (S II: 91) for which expectations will be ordered as means to ends. At this point Vailati meets James and the other Italian pragmatists: the will determines the purposes and on them the monistic claims of idealism and the rationalist claims of positivism have no power. There are several purposes and they depend on the individual as he/she emerges from the socio-historical development, anti-deterministically seen as a necessary but not sufficient condition.

6 In conclusion, we can say that Vailati was closer to his "magical" friends much more than is usually thought. If one considers Calderoni's reliance on Vailati's theses and, in addition, considers Calderoni's own theses (other than those he expressed in his debate with Giuliano il Sofista), one can say that much like the American pragmatists, the 
common project that united the Italian pragmatists was deeper and stronger than some of the members of the movement thought. ${ }^{8}$

7 A final philological question can be asked about what the Italian pragmatists as a group understood about the original American philosophy and what they added to it. Surely, as a group, they understood that pragmatism opposed both positivism and rationalism, while they remained more confused about the distinction between pragmatism on the one hand and Berkeley's idealism and Locke's empiricism on the other. As for rationalism, they identified Descartes and Kant as theoretical adversaries, exactly as their American counterparts had. ${ }^{9}$ They also understood the thick sense of experience that pragmatism advocated and the overthrow of the ancient dualisms between theory and practice, mind and body, and norms and descriptions that was the inevitable implication of the pragmatic maxim. However, they knew only a few of Peirce's writings and only a few more by James - they missed the sophisticated mathematical, phenomenological, semiotic, and metaphysical views that Peirce and James developed in the last phase of their lives. In particular, Vailati was unfamiliar with the intersection of Peirce's studies on continuity and abduction, ${ }^{10}$ the latter a method of reasoning that would have opened up Vailati's views to different, logical and mathematical landscapes.

What did the Italian pragmatists add to American pragmatism, leading Calderoni to claim that Italian pragmatism was an "original" form? They added an existentialist ${ }^{11}$ and even nihilist ${ }^{12}$ leaning that reverberated in their theory about values choice. This theory of values choice was the link between the magical and logical varieties of pragmatism and was also the origin of some extremely innovative research, like that conducted by Calderoni in the field of economics (Calderoni 1906). Italian pragmatists embraced the philosophical movement from the U.S. because they were looking for answers to vital problems, a thirst that was evident in Papini and also in the skeptical attitude of Prezzolini. As the correspondence with Papini confirms (Vailati 1971: 319-473), Vailati comprehended this existential drive and tried to put it in philosophical terms with the idea of the "third pragmatism." In the course of applying Vailati's ideas to economics and ethics, Calderoni, who was Vailati's pupil, had implicitly accepted the third brand of pragmatism advocated by his mentor much more than he ever admitted. The use of the collective name - the Florentine Pragmatist Club - under which all the important pragmatists authored the article that distinguished the three kinds of pragmatism and the intersections among them, was an index of the common belonging they professed in the years 1905-6, the years in which Vailati lived in Florence and in which Leonardo published its most important material.

\section{Action and Creation. The Peak and the End of Italian Pragmatists' Common Project}

9 I want to dedicate the last part of this paper to a topic that can illuminate the kind of theoretical attitude that united the participants in the club, a topic that reveals both their strength and their weakness. The topic is the conception of action as creation, whose theoretical side could be seen in the bond between the universal and the particular.

In December 1903, Papini, 22 years old at the time, published an article in Leonardo about the "Death and Resurrection" of philosophy. He adopted his usual apocalyptic tone. He clearly condemned intellectualist abstraction and generalization as a perennial error in 
philosophy and identified dualisms between theory and practice, generality and particularity, as the consequences of this erroneous starting point. Philosophical resurrection must involve turning the generalizing point of view upside down, as well as "a practical research and creation of the particular and the personal" (L I/11-12, 20 dicembre 1903: 7). Some of the consequences of this resurrection were simply weird, such as an appreciation for studies on single strange or miraculous events, magic, and egology, but Papini also describes the unity of theory and practice, and the improvement of technology as a necessary consequence. After reading the article, Vailati wrote to Papini highly praising the idea of individualization of ideas and of moving to a radical psychology of philosophy, ${ }_{13}^{13}$ which would make the link between philosopher and philosophy much more evident and clear. In a second letter, he takes another step in Papini's direction. This magical, practical, creative activity is simply what any art or science does; he therefore attacks Papini because he thinks that philosophy is special in this sense, different from other arts and sciences. Certainly, Vailati stresses that creation cannot be ex-nihilo and criticizes Papini for allowing too much freedom to the will. ${ }^{14}$ However, after Papini's response, Vailati understands that the real difference between his philosophical notions and Papini's is in the method of this transformation of the world through the embodiment of ideas into particulars. As he says: "I have no a priori objection to the possibility of educating our will and to its extension to further domains. However, I believe that the verification of this possibility should be sought more in experiment and induction than in speculation and intuition." (Vailati 1971: 391). The difference is in the tools but not in the goal: Vailati thinks that the enlargement of the realm of will depends on mediate tools of knowledge, while Papini thinks of these tools as immediate.

11 In a subsequent issue of Leonardo, Papini returned to the same topic in an article titled "Martha and Mary, from contemplation to action" (L II/1, marzo 1904: 8). Here Papini stressed that there is no distinction between the external and internal consciousness and that consciousness itself is always act and change. Papini considers the magical attitude as one that emphasizes this normal situation until ideas are transformed into reality: "It is a difference of measurement not of nature," he concluded (L II/1, marzo 1904: 8). The great logician Vailati was not opposed to this goal. In a letter dated November 21, 1904, Vailati, almost 20 years older than Papini, attempted to make his young friend aware that this revolution in philosophy was somehow the dream of many philosophers in the past: concepts are means to an end-in-view, and facts (their production and prediction) are the goal of any science. ${ }^{15}$ Vailati tried also to fix Papini's attention on the research of general ideas as an effective means of reaching the goal of facts, as an organ that helps produce them. Vailati also explained the extent to which creativity and imagination are tools for creating those general ideas, which in turn are tools for the creation of facts. This debate occurred before Vailati moved to Florence. After he moved, Leonardo changed and many of the subsequent articles show that Vailati's idea of saving Papini's dream and aim was at the foundation of the pluralist unity that Italian pragmatists found in their club. As we have seen, a united viewpoint appeared in April 1905 under the name the "Florentine Pragmatist Club." In this article, the Leonardians recognized that there were three kinds of pragmatism, but they identified some common characteristics: the softening of theories and beliefs; the relationship between general and particular; the choice of topics according to the ends in view; the culture of believing; the "corridor" theory, according to which pragmatism is a method of inquiry and not a system. We are unable to go deeply into all these commonalities, but I want to underline the conclusion of the theoretical 
part of the article, in which the Leonardians say that "it is easy to see the relationship" among the theoretical topics: "The common goal is to act; that is, to strengthen our power to modify things. In order to act, you must also forecast and in order to forecast with certainty you must have well-formed sciences which are fit for the task and verifiable. From induction to the Will to Believe there is a continuity which is provided by the common goal: the aspiration to be able to act" (L III/2, aprile 1905: 46). In a later paper Papini points out that the difference between pragmatist and positivist explaining that in the former previsions and consequences are considered to be matters of definition and interpretation as well as of practical application (L V/1, febbraio 1907: 26-38). Leonardians never reached Peirce's theory of modality and its application to the pragmatic maxim, but they were well aware that rationalism, positivism, and empiricism were far away from the pragmatic understanding of ideas. The theoretical bond between the kinds of pragmatism consisted in keeping clear the continuity between induction and the "Will to believe"; that is, in Prezzolini's words, between the first floor in which science works as doorman and the second floor where there is an orderly ability to create (L IV/4, ottobre-dicembre 1906: 355). This was the particular, theoretical addendum of the Italians to the original American movement: pragmatism as a way to create. This is why they could be so inclusive with respect to science, poetry, religion, and art - in every field we can see the act of creation. In the few months they worked together, Italian pragmatists thought that creative power must be a particular action that is connected to the generality of ideas. In creation we see these ideas at work, in concreto. An issue of Leonardo in June 1905 published three papers on "Belief and Will" by Calderoni, Papini, and Vailati. They all identified the capacity of foresight as characteristic of the voluntary will. Papini characterized foresight as an "experiment" and listed various kinds of experiments, from the scientific to the "personal," pointing out that the pragmatist method implies the reversal of the usual doctrine concerning the influence of what we know on what we do. The contrary is also true: what we do influences what we know. The passage from direct "intuition" of his early writings to indirect "experiment" was a huge step for Papini, and possibly the point at which Italian pragmatists could recognize a common conception of "creation" as "continuity between induction and the will to believe," the point at which they could insert their existential leanings into the pragmatist pattern (L III/3, giugno-agosto 1905: 127-8). ${ }^{16}$ On the other side of the equation, Vailati deepened his focus on both the need for the "use and construction of examples" and for "contemplation and representation of ideal, or even fantastic, situations" that it would be unscientific and unreasonable to forbid (S1: 59-66).

This was a high point of their common experience. It was a moment in which they belonged to pragmatism fully. In a book written with Rosa Calcaterra and Giancarlo Marchetti, we proposed some basic characteristics that classic pragmatists shared: the acceptance of the pragmatic maxim, evolutionism as a method, continuity between reality and knowledge, anti-Cartesianism, acknowledgment of mediate forms in epistemology, and an intertwinement among normative sciences (and possibly antiKantianism) (Calcaterra, Maddalena \& Marchetti 2015: 13-8). If you accept those points, it becomes clear that Papini's passage to "personal experiment" and the Italian pragmatists drive to unite imagination and will-deduction-induction into a single continuous action was the most advanced point of their research. They touched upon something new and important for the general story of pragmatism in that moment. After Vailati moved from Florence in 1906, he became more and more attentive to fighting against vagueness and for precision, while Papini moved closer to occultism. However, for a moment they 
proposed an original form of pragmatism in which love for experiment as particular action, rich realism well beyond any datum, an ampliative form of deduction and psychology, a passion for science, and existential questions coexisted. To build something theoretically new they needed a far most advanced study of mathematical continuity and the semiotic bases of logic, in order to understand that some experiments are simply the way in which we act upon the continuity of reality, a reality that is always changing. Moreover, they should have undertaken an experiment - such as Peirce's existential graphs - in which they could capture reasoning as an act that happens through that continuity, performing a synthesis, namely, a recognition of identity through change. Italian pragmatists stressed the need for a kind of creative knowledge that would involve not only the analysis of concepts but also the psychology underpinning our emotions, representations, and choices of value. Perhaps they also needed a different conception of reasoning, and in particular of synthetic reasoning. Unfortunately, they did not have the same tools that American pragmatists had. And when Vailati left Florence in 1906, they lost the united track they had found. However, James was right in thinking that they were up to something new - a sort of synthetic, existential pragmatism that has only been vindicated with recent mathematical discoveries (Zalamea 2012; Maddalena 2015).

\section{BIBLIOGRAPHY}

AA.VV., "Il pensiero di Giovanni Vailati," Rivista critica di storia della filosofia, vol. 18, No. 3, lugliosettembre 1963, 275-523.

AA.VV., "Il pensiero di Mario Calderoni," Rivista critica di storia della filosofia, vol. 34, No. 3, lugliosettembre 1979, 243-426.

BenVenuto Beppe, (2003), Giuseppe Prezzolini, Palermo, Sellerio.

BIONDI Marino, (2001), Giuseppe Prezzolini: diario di un secolo, Bolzano, Centro di Cultura dell'Alto Adige.

BIONDI Marino, (2006), "Papini saggista. La critica, il giudizio, la memoria," in Ceccuti Cosimo (ed.), Papini e il suo tempo, Firenze, Le Lettere, 121-208.

BORDOGNA Francesca, (2015), “'Thought and Action': William James, the Magic Pragmatists, and the Fascist Mystics," Second European Pragmatist Conference, Paris, 11 September.

CALCATERRA Rosa Maria, MADDALENA Giovanni \& Giancarlo MARCHETTI (eds), (2015), Il pragmatismo dalle origini agli sviluppi contemporanei, Roma, Carocci.

CALDERONI Mario, (1906), Disarmonie economiche e disarmonie morali: saggio di un'estensione della teoria ricardiana della rendita, Firenze, Lumachi.

CASINI Paolo, (2002), Alle origini del Novecento. "Leonardo," 1903-1907, Bologna, Il Mulino.

CILIBERTO Michele, (1983), “Tra ‘societas christiana' e cesarismo: Giovanni Papini,” in Gentili

Stefano (ed.), Giovanni Papini nel centenario della nascita, Milano, Vita e Pensiero, 77-104. 
COLAPIETRo Vincent, (2007), “'Di al tuo amico Giuliano...' Gli entusiasmi di James e le riserve di Peirce," in Maddalena Giovanni \& Tuzet Giovanni (eds), I pragmatisti italiani tra alleati e nemici, Milano, AlboVersorio, 97-114.

DAL PRA Mario, (1984), Studi sul pragmatismo italiano, Napoli, Bibliopolis.

DE WAAL Cornelis, (2004), On Pragmatism, Belmont, Wadsworth.

GARIN Eugenio, (1963), “Giovanni Vailati nella cultura italiana del suo tempo," Rivista critica di storia della filosofia, 18 (3), 275-93.

GENTILI Stefano, (2003), “L'altra metà. Prezzolini e Papini," in Ceccuti Cosimo (ed.), Prezzolini e il suo tempo, Firenze, Le Lettere, 113-43.

JAMES William, (1906), “G. Papini and the Pragmatist Movement in Italy," The Journal of Philosophy, Psychology and Scientific Method, 3 (13), 21 June 1906, 337-41.

JAMES William, (1992-2004), The Correspondence of William James (CWJ), ed. by Ignas K. Skrupskelis \& Elizabeth M. Berkeley, Charlottesville and London, University of Virginia Press.

LEONARDO (1903-1907). The abbreviation "L" is followed by volume Roman number, issue Arab number, date, and page. For instance: L I/1, 4 gennaio 1903: 1.

MADDALENA Giovanni, (2007), “Giovanni Vailati e l'arte di ragionare," in Maddalena Giovani \& Tuzet Giovanni (eds), I pragmatisti italiani. Tra alleati e nemici, Milano, Alboversorio, 23-42.

MAdDAlEna Giovanni, (2010), "Peirce and Vailati on Semiotics and Freedom," Cognitio, 1 (11), $58-68$.

MAdDALENA Giovanni, (2015), The Philosophy of Gesture, Montreal, McGill- Queen's University Press. MAdDalena Giovanni, (2019), “Anti-Kantianism as a Necessary Characteristic of Pragmatism," in Pragmatist Kant, Nordic Pragmatist Network.

MAdDALENA Giovanni \& Michela Bella (2017), “William James and Italian Pragmatism," in David H. Evans (ed.), Understanding James, Understanding Modernism, New York, Bloomsbury, 249-58.

MADDALENA Giovanni \& Giovanni TUZET (eds), (2007), I pragmatisti italiani tra alleati e nemici, Milano, AlboVersorio.

LIVINGSTON Alexander, (2016), Damn Great Empires! William James and the Politics of Pragmatism, Oxford, Oxford University Press.

O'HARE MCCORMiCK Anne, (1926), “Behind Fascism Stands a Philosophy," New York Times Magazine, Sept. 26, 2-3, 18.

PAPINI Giovanni, (1906), Il crepuscolo dei filosofi, Milano, Società Editrice Lombarda.

PAPINI Giovanni, (1911 [1922]), L'altra metà, Firenze, Vallecchi (4 ed.).

PAPINI Giovanni, (1948 [1994]), Passato remoto, Firenze, Ponte alle Grazie (2 ed.)

PAPINI Giovanni, (1977), Opere. Dal “Leonardo" al futurismo, Milano, Mondadori.

PAPINI Giovanni \& Ardengo SOFFICI, (2003), Carteggio IV (1919-1956). Dal primo al secondo dopoguerra, Roma, Storia e Letteratura.

PIGA Francesco, (1983), "Papini e Nietzsche," in Gentili Stefano (ed.), Giovanni Papini nel centenario della nascita, Milano, Vita e Pensiero, 244-54.

PREZZOLINI Giuseppe, (1907 [1971]), L'arte di persuadere, Firenze, Lumachi. 
PREZZOLINI Giuseppe, (1925), Le fascisme, Paris, Éditions Bossard.

PREZZOLINI Giuseppe, (1978), Diario 1900-1941, Milano, Rusconi.

PREZZOLINI Giuseppe, (2001), "Fascismo e cultura," in Biondi Marino, Giuseppe Prezzolini: diario di un secolo, 87-100.

QUARANTA Mario, (1986), "Positivismo e marxismo di fine secolo. Lettere di Giovanni Vailati a Guglielmo Ferrero," Schema, 8 (2), nuova serie, 269-83.

QUARANTA Mario, (2015), La discussione filosofica nelle riviste del novecento (1900-1970), Padova, Saperi.

READ Herbert, (1936), “The Significance of William James," The Spectator, Oct. 23, 24.

SANTUCCI Antonio, (1963), Il pragmatismo in Italia, Bologna, il Mulino.

SEGRE Umberto, (1963), "Vailati e la discussione sul socialismo," Rivista critica di storia della filosofia, 18 (3), 487-98.

VAILATI Giovanni, (1971), Epistolario (1891-1909), Torino, Einaudi.

VAILATI Giovanni, (1987), Scritti (vol. 1: Scritti di filosofia; vol. 2: Scritti di scienza; vol. 3: Scritti di scienze umane), ed. by Mario Quaranta, Bologna, Arnaldo Forni.

VILLA Guido, (1962), Sul pragmatismo logico di Vailati e Calderoni: la questione delle varietà del pragmatismo, "Memorie della Accademie delle Scienze di Bologna. Classe di scienze sociali," 10 (5), 188-213.

ZALAmEA Fernando, (2012), Synthetic Philosophy of Contemporary Mathematics, New York, Urbanomics.

\section{NOTES}

1. In 1911, Papini wrote the book L'altra metà, in which he defined the two kinds of pragmatism that they held during the epoch of Leonardo (1903-1907). On the one hand, there was "il vero pragmatismo, il custode della vecchia induzione, il profeta della previsione, l'analizzatore dei motivi e dei ripieghi delle scienze, il sentenziatore cauto dei sensi e dei non sensi" (Papini 1911: 17). On the other hand, there was "il gran sogno taumaturgo non mai rinnegato: l'uomo signore del mondo, la mente creatrice di verità, la volontà madre di miracoli, tutto l'universo una pasta duttile e docile sotto le mani del nuovo Iddio" (ibid.). As he said in the article "Avvertimento" (1913): "Presso di noi il Pragmatismo si divise quasi nettamente in due sezioni: quella che si potrebbe dire del Pragmatismo logico e quella del Pragmatismo psicologico o magico. Alla prima appartenevano Vailati e Calderoni ai quali moltissimo deve [...] la teoria della scienza e la logica considerata come studio del significato delle proposizioni e delle teorie. La seconda era composta da me e da Prezzolini e noialtri, spiriti più avventurosi, più paradossali e più mistici svolgemmo soprattutto quelle teorie che ci facevano sperare un'efficacia diretta sul nostro spirito e sulle cose." (Papini 1977: 7). For a theoretical formulation of the second stripe of Pragmatism, see L'arte di persuadere by Giuseppe Prezzolini (1907).

2. The dialectic exchange between Prezzolini and Calderoni started in L II/3, novembre 1904: 3-8. Hereafter, I will use L for referring to the journal Leonardo, followed by volume Roman number, issue Arabic number, date, and page. The aforementioned reference is to Leonardo, volume II, issue 3, November 1904, pages 3-8. The discussion on pragmatism continued on L III/1, febbraio 1905: 15-21 and ended on L III/2, aprile 1905: 48. As for the history of Leonardo, see Casini 2002, and Quaranta 2015. 
3. In G. Papini and the Pragmatism Movement in Italy (1906) James writes: "Pragmatism according to Papini [...] is like a corridor in a hotel, from which a hundred doors open into a hundred chambers. In one you may see a man on his knees praying to regain his faith; in another a desk at which sits some one eager to destroy all metaphysics; in a third a laboratory with an investigator looking for new footholds by which to advance upon the future. But the corridor belongs to all, and all must pass there. Pragmatism, in short, is a great corridor theory." (James 1906: 33).

4. In 1922, the year of the fascist march on Rome, Prezzolini wrote in his diary: "il fascismo è grossolano, incolto, mette sotto i piedi la libertà e minaccia la politica estera." (Prezzolini 1978: 363). Some years later, he published in France an essay called Le fascisme (1925), hit by fascist censorship (for the history of this work see Biondi 2001). In a letter to Soffici on the 15th of September 1919, Papini writes: “L'Italia, in apparenza, è oggi rappresentata da tre energumeni sifilitici [syphilitic energumenes]: D’Annunzio, Mussolini e Marinetti. Ma tu sai che l'avvenire non è lì e non è coi loro." (Papini \& Soffici 2003: 45). Michele Ciliberto wrote about Papini's late connection to fascism: "Non è dunque il fascismo come ristrutturazione istituzionale, statuale, in termini reazionari di massa, della nazione italiana, che attrae Papini. E neppure lo stimolano [...] le proposte di tipo corporativistico [...]. Ciò che nel fascismo gli sembra essenziale non è l'organizzazione delle masse [...] Ciò che lo attrae e convince è la figura del duce, del capo, del cesare, il ruolo da essa svolto sul piano politico e anche ideale, culturale." According to Ciliberto, the philosophical link between the late Papini and fascism is not the ideology but the strong attraction for cesarismo, the need of a Cesar, as typical character of Italian history (Ciliberto 1983: 95). In his work about fascism, Prezzolini says: "La parola d'ordine del fascismo è azione, non pensiero. Non è stato preparato o proceduto da un movimento ideale; si ricollega alla guerra, che non dà modo al pensiero di esercitarsi, e alla giovinezza, che non è la stagione della vita più adatta alla riflessione [...] Il fascismo è, sotto questo aspetto, indice di grossolanità e impoverimento intellettuale. Leggendo la produzione degli anni del dopoguerra e confrontandola con quella anteriore si ha la sensazione che il progresso allora raggiunto si sia in parte perduto. $\mathrm{E}$ un po' come immaginare dei contadini che tolgano da una borsa chirurgica trovata nei campi i ferri pieni di ruggine e si mettano a fare delle operazioni!" (Prezzolini 2001: 87-8).

5. Vailati's political writings are collected in the third volume of his complete works (S3). Segre 1963, and Quaranta 1986 provided a good account of his political views.

6. In L'arte di persuadere (1907), Prezzolini says: "Non v'è dunque grande differenza [...] tra il ragazzo che nasconde una scampagnata con una lezione straordinaria e attribuisce al gatto $\mathrm{i}$ furtarelli commessi nella credenza casalinga, e lo scienziato che inventa atomi, particelle, eteri ed altri personaggi della sua mitologia scientifica per i bisogni di coesione della scienza. Lo scienziato è un bugiardo utile collettivamente, il bugiardo è uno scienziato utile egoisticamente. La bugia è dunque il portone d'ingresso della scienza." (Prezzolini 1971: 105). In 1907 Vailati writes a long review of Prezzolini's book under the head of Un manuale per $i$ bugiardi. In the review, he agrees with Prezzolini's paradoxes: "Perfettamente fondate a questo riguardo, nonostante il loro carattere paradossale, mi sembrano le considerazioni che conducono il Prezzolini, nel suo volume L'arte di persuadere, a stabilire un parallelo tra le costruzioni delle 'bugie' e quella delle teorie scientifiche." (S1: 82).

7. In a letter written to Papini in 1903, Vailati said that the apriori is a "illusione dell'evidenza, derivante [...] da una rapida oscillazione tra due significati affatto diversi di una data frase" (Vailati 1971: 371). In his first book, Crepuscolo dei filosofi, Papini follows Vailati's teaching: "L'apriori, in Kant, è piuttosto un articolo di fede che una teoria critica, e il devoto kantiano dovrebbe aggiungerlo alle cose che bisogna credere senza poterlo dimostrare." (Papini 1906: 29). For an overview of Vailati's attacks to Kant see Maddalena (2015: 16-8).

8. For the mutual links between Calderoni and his master (and their relationship with the American pragmatists) see the issues dedicated to their thoughts by Rivista critica di storia della filosofia in 1963 and 1979, as well as Villa 1962. 
9. For an overview of anti-Kantism as fundamental characteristic of pragmatism see Maddalena (2015: 10-9). The problem with anti-Kantism as intrinsic to pragmatism is always related to Peirce's attitude towards the German master. Peirce changed his mind over the years and arrived to a profound anti-Kantism. The story of this change is documented in Maddalena 2019.

10. Vailati wrote only one review of Peirce's articles (see S1: 361-2).

11. The existentialist way is the real element of novelty that the Italians added to pragmatism (Maddalena \& Tuzet 2007). According to Sandro Gentili, Prezzolini and Papini tried to find a discipline committed to a practical, existential aim. "Cercarono di disciplinarsi attraverso uno scopo che abbia una possibilità di traduzione pratica e sembra indirizzarsi a entrambi, in una sorta di pragmatismo non più gnoseologico ma esistenziale." (Gentili 2003: 133). In another article, Biondi maintains: "L'intreccio fra cultura e vita era strettissimo, ed era un intreccio pragmatista. Un pragmatismo cognitivo ed esistenziale." (Biondi 2006: 144). Benvenuto 2003 considers the young Prezzolini as an existentialist nihilist.

12. Francesco Piga worked on the connection between Papini and Nietzsche. "È evidente che l'invettiva di Papini, il tono forte e accusatore degli articoli del 'Leonardo' e delle stesse pagine de Il Crepuscolo dei filosofi e di Un uomo finito risalgono scopertamente alla lettura di Nietzsche." (Piga 1983: 247). Papini's interest in Nietzsche was a stimulus for Vailati; in a letter sent to Papini in 1904, Vailati wrote: "Che Nietzsche dicesse male di Spencer, prova che sentiva il bisogno di contraddirlo come ogni discepolo intelligente ha bisogno di contraddire al suo maestro. La sua dottrina filosofica porta l'impronta di una continua evoluzione verso la teoria dell'evoluzione, accompagnata dal desiderio di oltrepassarla." (Vailati 1971: 383). The same statement appears in the review that Vailati wrote on Orestano's book about the strongholds of Nietzsche's thought (see S1: 329-33).

13. In the letter Vailati writes: “[...] la 'filosofia,' dopo essere andata diventando a poco a poco [...] la storia di se medesima, non deve fermarsi a mezza strada e deve trasformarsi risolutamente nella [...] psicologia della filosofia o, più precisamente, nella 'psicologia dei filosofi' (PhilosophenPsychologie, la quale comprende invece lo studio delle manifestazioni meno individuali, più gregarie dello spirito umano: politica, tecnologia, folklore, religione, etc.) Ciò che dici della filosofia come documento, non potrebbe essere meglio detto, ed è impossibile resistere all'impulso di trattare subito come documento anche quella stessa tua filosofia che si propone di studiare le altre in tal modo." (Vailati 1971: 384).

14. “[...] questa 'attività creatrice, magica,' etc., da che cosa distingue la filosofia? Se essa non la distingue dall'arte [...] non la distingue neppure dalle scienze particolari, ciascuna delle quali, nel proprio campo speciale, è o può essere altrettanto creatrice o magica quanto l'arte e la filosofia nel loro. Un chimico che compone un nuovo profumo o un nuovo veleno, un ingegnere che fa un impianto elettrico, un allevatore che crea una nuova specie o varietà di bachi da seta o una nuova razza di cani, uno psicologo o un educatore che forma (o perverte) un'anima, etc., sono perlomeno altrettanto creatori quanto il costruttore di nuovi schemi filosofici, o il cesellatore di nuovi aforismi o il coniatore di nuove 'parole d'ordine' (o di 'disordine') atte a servire nelle logomachie filosofiche, o lo scopritore di nuove giustificazioni per gli istinti umani, etc., etc. [...] Le verità, le leggi di natura, etc., sono rotaie su cui i fatti, e in particolare le nostri azioni, si devono muovere; tu, dal tuo istinto di libertà, sei portato invece a concepire l'uomo come una nave che crea la propria rotta e non ha solchi davanti a sé, ma solo di dietro, cioè quelli che essa stessa fa." (Vailati 1971: 386-7).

15. Vailati says: "Che vi sia una differenza tra un concetto e un fatto, tra un'idea astratta e una sensazione concreta, non vi sarà nessuno uomo che te lo neghi. Sul valore di questa differenza, cioè, in altre parole, sulla questione: quale delle suddette due categorie di fatti mentali abbia carattere di fine rispetto all'altra (nel senso ben preciso di 'fine,' che tu determini così bene nelle prime pagine di quel capolavoro che è l'opuscolo sulla previsione); sulla questione insomma del compito dei concetti e delle idee generali, come puoi attribuire ai filosofi in genere, o anzi alla 
filosofia, di avere un solo parere, quello opposto al tuo, mentre una metà almeno (il ballottaggio si potrebbe tentare) dei più grandi filosofi del passato (i quali lo sono anche del presente) è precisamente d'accordo con te, salvo lievi sfumature dovute al diverso modo d'esprimersi e alle diverse lingue in cui scrissero, nel sostenere che i concetti sono dei mezzi e che i fatti (cioè la loro produzione e previsione) sono il fine di ogni scienza e d'ogni speculazione." (Vailati 1971: 425-6).

16. In the same issue Papini published his article on the congress of psychology held in Rome in 1905 (123-4). The three papers are in fact the summaries of the papers that Vailati, Calderoni and Papini read in that place. Another review of the congress is by Vailati (S3: 153-4). During the congress the Italian pragmatists met William James, who was the guest star of congress. In Passato remoto, many years later, Papini remembered their private meeting during those days, underlining James's kindness and openness of mind (Papini 1948). James famously wrote to his wife Alice an enthusiastic comment about the encounter (CWJ, 11,26). See also Maddalena \& Bella 2017.

\section{ABSTRACTS}

According to the standard interpretation, Italian pragmatism is split into two groups. On the one hand is the mathematician Giovanni Vailati, Peano's former collaborator, and his disciple, the economist Mario Calderoni. On the other hand, there are the two "brats," Giovanni Papini and Giuseppe Prezzolini, naïve philosophers with eccentric ideas. While Vailati and Calderoni followed Peirce's mathematical and logical pragmatism, the other two articulated a "magical" pragmatism, a kind of relativist, post-modern version of the original American movement. The paper shows that this narrative is incomplete. During the years 1905-6, while Vailati was living in Florence, Italian pragmatists listed three kinds of pragmatism among themselves. Relying on the third stripe, attributed to Vailati, they found a more Unitarian, theoretical project that united the will to belief and the precision of reasoning. The unity did not last very long because Vailati moved from Florence in 1906. However, the common project from 1905-6 remains the highest peak of their awareness of pragmatism and, possibly, an original way to interpret it.

\section{AUTHOR}

\section{GIOVANNI MADDALENA}

Università del Molise

maddalena[at]unimol.it 